陸上競技女子長距離選手における貧血状態と血中アミノ酸濃度の関連 門馬 怜子 ${ }^{1}$, 熊谷 仁 $^{2,3,4}$, 王子田 萌 $^{5}$, 家光 素行 ${ }^{5}$, 前田 清司 $^{4}$

\title{
Relationship between anemia and circulating levels of amino acids in female endurance athletes
}

\author{
Reiko Momma ${ }^{1}$, Hiroshi Kumagai ${ }^{2,3,4}$, Moe Oshiden ${ }^{5}$, Motoyuki Iemitsu ${ }^{5}$ and Seiji Maeda ${ }^{4}$ \\ 1筑波大学人間総合科学研究科体育学専攻，７305-8574 茨城県つくば市天王台 1-1-1 (Graduate School of Comprehensive \\ Human Sciences, Master's Program in Health and Sport Sciences, University of Tsukuba, 1-1-1 Tennodai, Tsukuba, \\ Ibaraki 305-8574, Japan) \\ 2 順天堂大学大学院スポーツ健康科学研究科, =270-1695 千葉県印西市平賀学園台1-1 (Graduate School of Health and \\ Sports Science, Juntendo University, 1-1 Hirakagakuendai, Inzai, Chiba 270-1695, Japan) \\ ${ }^{3}$ 日本学術振興会，７102-0083 東京都千代田区静町 5-3-1 (Japanese Society for the Promotion of Science, 5-3-1 Kojimachi, \\ Chiyoda, Tokyo 102-0083, Japan) \\ 筑波大学体育系， ３05-8574 茨城県つくば市天王台1-1-1 (Faculty of Health and Sport Sciences, University of Tsukuba, \\ 1-1-1 Tennodai, Tsukuba, Ibaraki 305-8574, Japan) \\ 5 立命館大学スポーツ健康科学部，７525-8577 滋賀県草津市野路東1-1-1 (Faculty of Sport and Health Science, Ritsumei- \\ kan University, 1-1-1 Nojihigashi, Kusatsu, Shiga 525-8577, Japan)
}

Received: May 23, 2017 / Accepted: August 30, 2017

\begin{abstract}
The symptoms of anemia, decreases in the levels of circulating red blood cells (RBC), hemoglobin $(\mathrm{Hb})$ and hematocrit $(\mathrm{Ht})$ lead to decrease endurance performance, and the risk of anemia increases in female endurance athletes. Although $\mathrm{Hb}$ is composed of a large amount of amino acids, the relationships between circulating levels of amino acids and RBC, $\mathrm{Hb}$ and $\mathrm{Ht}$ in female endurance athletes have not been clarified yet. Thus, the purpose of the present study was to investigate the relationship between circulating levels of amino acids and $\mathrm{RBC}, \mathrm{Hb}$ and $\mathrm{Ht}$ in female endurance athletes. Twenty-four female endurance athletes $(19.8 \pm$ 0.2 years) participated in this study. We measured circulating levels of $\mathrm{RBC}, \mathrm{Hb}$ and $\mathrm{Ht}$ from blood. Also, we measured circulating levels of amino acids from plasma by use of comprehensive analysis. The levels of circulating $\mathrm{RBC}, \mathrm{Hb}$ and $\mathrm{Ht}$ in all subjects were within the normal range. We found that circulating taurine levels were significantly correlated with $\mathrm{RBC}(\mathrm{r}=0.48$, $\mathrm{p}<0.05), \mathrm{Hb}(\mathrm{r}=0.44, \mathrm{p}<0.05)$ and $\mathrm{Ht}(\mathrm{r}=0.42, \mathrm{p}<0.05)$ in female endurance athletes. In the present study, we demonstrated that circulating taurine levels were significantly associated with $\mathrm{RBC}, \mathrm{Hb}$ and $\mathrm{Ht}$ in female endurance athletes. These results suggest that circulating taurine levels may be a predictor of anemia and treatment strategy for anemia.
\end{abstract}

Jpn J Phys Fitness Sports Med, 66(6): 391-397 (2017)

Keywords : anemia, amino acids, circulating taurine levels, female endurance athlete

緒言

近年，世界レベルの大会に扔いて，女性アスリートの 活躍を目にする機会が増えている。このような活躍の一 方で，女性アスリートは，男性アスリートとは異なる女 性特有の身体的な問題を有する，その一つに「貧血」が 挙げられる，女性には「月経」という重要な生殖機能が 存在し, 月経時には生理的出血を伴うことから男性より も貧血を発症する可能性が高くなる ${ }^{1)}$. 貧血の状態では, 酸素の運搬に関連する赤血球やへモグロビン, ヘマト クリットの血中濃度は減少し,「息切れ」や「疲れやす
い」といった競技力の低下に繋がり得る症状を引き起こ す。この貧血は，女性アスリートの中でも特に陸上競技 の長距離選手に多い疾患である ${ }^{1)}$ ，長距離走種目におい て, 貧血は競技成績の低下に直接的に影響を及ぼすこと から，その早期発見や早期治療が極めて重要である。

アミノ酸は炭素 $(\mathrm{C})$, 酸素 $(\mathrm{O})$, 水素 $(\mathrm{H})$, 窒素 (N) の 4 元素で構成され，ヒトの生体の約 $20 \%$ 占め るタンパク質の主要な成分である。このアミノ酸は，ヒ トの体内で合成することが出来る非必須アミノ酸と, 体 内で合成することが出来ない必須アミノ酸に分類され る。また，必須アミノ酸の中でもバリン，ロイシン，イ 
ソロイシンは分岐鎖アミノ酸 (Branched-chain amino acid：BCAA）と呼ばれ，筋肉の恒常性の維持および機 能発揮に重要であることが明らかにされている2). 一方 で, 酸素の運搬に重要であるへモグロビンは, へムとい う鉄を含む赤い色素とグロビンというタンパク質から構 成される複合タンパク質である。グロビンは $\alpha$ 鎖と 146 個のアミノ酸から成る $\beta$ 鎖の 2 種類のポリペプチドによ り構成されることから，アミノ酸は血中のへモグロビン 濃度などの貧血状態を反映する指標と関連する可能性が ある ${ }^{3)}$. しかし，貧血のリスクが高い女性アスリート， 特に女性の長距離選手を対象とした検討は一切行われて いないのが現状である。

このような背景から, 我々はへモグロビンなどの貧血 状態を反映する指標とタンパク質の構成に関連するアミ ノ酸は関係するという仮説を立て，貧血のリスクが高い 陸上競技女子長距離選手に扔ける血中アミノ酸濃度と貧 血状態の関連について検討することを目的とした。この 目的を検証するため, 本研究では陸上競技女子長距離選 手に扔いて，貧血状態を反映する血中の赤血球数，へモ グロビン濃度抢よびヘマトクリット值と血中アミノ酸濃 度の関連について検討を行った。

\section{方 法}

対象者 本研究では, 大学陸上競技部に所属し長距離種 目を専門とする女子選手24名を対象とした. 対象者には, 測定の前日からアルコール・カフェインの摂取，および 激しい運動を避けるように指示し, 測定は 1 晚の絶食状 態で実施した。実験に先立ち，対象者全員に実験の目的 および測定内容を説明し，実験に参加する同意を得て測 定を実施した。な㧍，本研究は立命館大学の倫理委員会 の承認を得て行った（BKC－人医－2016-010）.

\section{測定項目}

\section{·身体特性}

体成分分析装置（Inbody770，インボディ・ジャパン） を用いて, 体重, 体脂肪率, 全身筋肉量を測定した。 また, BMI（Body Mass Index）については，体重 $(\mathrm{kg}) /$ 身長 $(\mathrm{m})^{2}$ により算出した。

\section{・貧血指標抢よび血中アミノ酸濃度}

肘正中皮静脈から採血を行い，貧血指標および血中ア ミノ酸濃度の測定を行った。貧血指標については，血 球成分および血清成分を用いて血中の赤血球数, へモ グロビン濃度拈よびへマトクリット值を評価した。ま た，血中アミノ酸濃度については，全自動アミノ酸分析 機 (Amino acid analyzer, JEOL JLC-500/V2, 日本電子 株式会社製）を用いて網羅的にアミノ酸を測定した。採 血により得られた血漿サンプルを $3 \%$ スルホサリチル
酸水溶液と等量混和し, 冷蔵庫で 1 時間放置した。その 後，混和したサンプルを遠心分離し $\left(4{ }^{\circ} \mathrm{C}, 3000 \mathrm{rpm}, 15\right.$ min), 上澄み液を濾過精度 $0.45 \mu \mathrm{m}$ のフィルタで滤過し 分析用サンプルとした. アミノ酸の測定は, ヒスチジン, イソロイシン, ロイシン, リジン, メチオニン, フェニ ルアラニン, スレオニン, バリン, アラニン, アンセリン, アルギニン, アスパラギン酸, シトルリン, システイン, シスタチオニン，グルタミン酸，グリシン，ヒドロキシ プロリン, モノエタノールアミン, オルニチン, プロリン, セリン，タウリン，チロシンとした。 さらに血中のアン モニア濃度および尿素を測定した。なお，血中アミノ酸 濃度の正常範囲については，株式会社SRLのアミノ酸分 析基準值一覧を参照した ${ }^{4)}$.

・アンケート調査

アンケートにより，競技歴，ベストタイム， 1 週間の 走行距離, 1 週間の練習頻度, サプリメント摂取の有無 （鉄剂, アミノ酸）を調査した。また, 日本産婦人科学会 の定める診断基準に基づき5)，対象者の続発性無月経の 有無について評価した。

統計処理 本研究結果は, すべて平均值士標準誤差で示 した. Shapiro-Wilk検定を用いて正規性の確認を行っ た後，Pearsonの相関関係抒よびSpearmanの順位相関 係数により貧血状態と血中アミノ酸濃度の関連を検討し た。また，日常的なサプリメント摂取の影響を除外す るため, 血中アミノ酸濃度と貧血指標の関連について 偏相関分析による解析を行った。なお，続発性無月経 を有する者とそうではない者における貧血項目の比較 には，対応のない $\mathrm{t}$ 検定を用いた，統計処理には，IBM SPSS Statistics 23 を用い，統計学的有意水準はいずれも $P<0.05$ とした.

\section{結 果}

Table 1 に被験者特性を示す。被験者の平均年齢は $19.8 \pm 0.2$ 歳, 身長は $159.7 \pm 0.9 \mathrm{~cm}, \mathrm{BMI} 18.9 \pm 0.3 \mathrm{~kg} /$ $\mathrm{m}^{2}$, 練習頻度は $6.5 \pm 0.1$ 回/週, $5000 \mathrm{~m}$ のベストタイム は960.2 \pm 4.3 秒, 走行距離は $110.2 \pm 16.5 \mathrm{~km} /$ 週であった。 $5000 \mathrm{~m}$ のベストタイムから，本研究の被験者は，競技 レベルの高い女子選手であった，貧血状態を反映する血 中の赤血球数は $429.7 \pm 6.3\left(\times 10^{4} / \mathrm{uL}\right)$, 血中へモグロビ ン濃度は $13.3 \pm 0.1 \mathrm{~g} / \mathrm{dL}$ ，へマトクリット值は $40.0 \pm 0.4 \%$ であった，なおこれらの貧血状態を示す指標はすべて正 常範囲内であった。また，アンケート調査の結果，鉄剂 のサプリメントのみを摂取している者が 3 名, アミノ酸 のサプリメントを摂取している者が 2 名, 鉄剤とアミノ 酸のサプリメントを併用摂取している者は 3 名であっ た。続発性無月経の有無について, 続発性無月経がない 
Table 1. Characteristic of studied subjects.

\begin{tabular}{lrll}
\hline & \multicolumn{2}{c}{$\mathrm{n}=$} & 24 \\
\hline Age (years) & 19.8 & \pm & 0.2 \\
Height (cm) & 159.7 & \pm & 0.9 \\
Weight (kg) & 48.3 & \pm & 0.8 \\
Body fat (\%) & 14.9 & \pm & 0.8 \\
Body muscle muss (kg) & 22.6 & \pm & 0.3 \\
Body mass index (kg/m $)$ & 18.9 & \pm & 0.3 \\
Career (years) & 8.7 & \pm & 0.5 \\
Personal best for 5000m (second) & 960.2 & \pm & 4.3 \\
Frequency of the $\mathrm{practices}$ (times/week) & 6.5 & \pm & 0.1 \\
Running distance (km/week) & 110.2 & \pm & 16.5 \\
Red blood cell (×104/uL) & 429.7 & \pm & 6.3 \\
Hemoglobin (g/dL) & 13.3 & \pm & 0.1 \\
Hematocrit (\%) & 40.0 & \pm & 0.4 \\
\hline Data
\end{tabular}

Data are shown as the mean $\pm \mathrm{SE}$.

と答えた者は 7 名, 続発性無月経があると答えた者は 17 名であった。また，続発性無月経を有する者とそうでな い者の間に, 血中の赤血球数 $\left(436.2 \pm 6.8\left(\times 10^{4} / \mathrm{uL}\right) \mathrm{vs}\right.$ $\left.414.0 \pm 11.5\left(\times 10^{4} / \mathrm{uL}\right), P=0.12\right)$, モグロビン濃度 $(13.4$ $\pm 0.2 \mathrm{~g} / \mathrm{dL}$ vs $13.1 \pm 0.2 \mathrm{~g} / \mathrm{dL}, P=0.27)$ ，拈よびへマトク リット值（ $40.3 \pm 0.4 \%$ vs $39.3 \pm 0.9 \%, P=0.22 ）$ は有意差 が認められなかった。

Table 2 に被験者の血中アミノ酸およびその代謝産物 の濃度を示す，対象者の血中アミノ酸濃度の平均值は, ヒスチジン以外の全てのアミノ酸において正常範囲内で あった，アミノ酸の一種である血中タウリン濃度は, 貧 血の指標である血中の赤血球数 $(r=0.48, P<0.05)$ （Fig. $1-\mathrm{A})$, ヘモグロビン濃度 $(r=0.44, P<0.05)$ (Fig. 1-B), およびへマトクリット值 $(r=0.42, P<0.05) \quad$ (Fig. 1-C) と有意な相関関係を示した。また, これらの相関関係を サプリメント摂取の有無で補正したところ，血中タウリ ン濃度と血中の赤血球数にのみ有意な相関関係が認めら れ（partial $r=0.44, P<0.05)$, 血中タウリン濃度とへモ グロビンおよびへマトクリット值には，有意傾向が認め られた (ヘモグロビン: partial $r=0.39, P=0.06$, ヘマトク リット : partial $r=0.37, P=0.09)$.

一方，その他の血中アミノ酸濃度については，貧血指 標との有意な関連は認められなかった，練習頻度は尿
素 $(r=0.50, P<0.05)$ と有意な正の相関関係を示し，リ ジン $(r=-0.46, P<0.05)$ およびアンセリン $(r=-0.49$, $P<0.05)$ とは有意な負の相関関係が認められた. しかし, ベストタイムや走行距離と血中アミノ酸濃度には有意な 関連が認められなかった。

\section{考察}

本研究では，陸上競技女子長距離選手における血中の 赤血球数掞よびへモグロビン濃度と血中アミノ酸濃度の 関連を横断的に検討した，本研究において，アミノ酸の 一種である血中タウリン濃度が貧血状態を反映する指標 である血中の赤血球数, へモグロビン濃度およびへマト クリット值と有意な正の相関関係が示された。 さらに, 偏相関分析の結果，鉄剤やアミノ酸のサプリメント摂取 の有無で補正後も, 血中タウリン濃度と赤血球数には有 意な相関関係が認められ，血中タウリン濃度とへモグロ ビンおよびヘマトクリット值には有意傾向が認められ た.これらの結果から，陸上競技女子長距離選手に扮いて, 血中タウリン濃度は血中の赤血球数, へモグロビン濃度 およびヘマトクリット值と関連する可能性が示された。

赤血球やその内部に存在するへモグロビンは酸素の運 搬に関連することから，これらの血中濃度が貧血状態を 反映する指標として沉用されている，赤血球の内部には 
Table 2. Plasma levels of amino acid and related metabolite in studied subjects

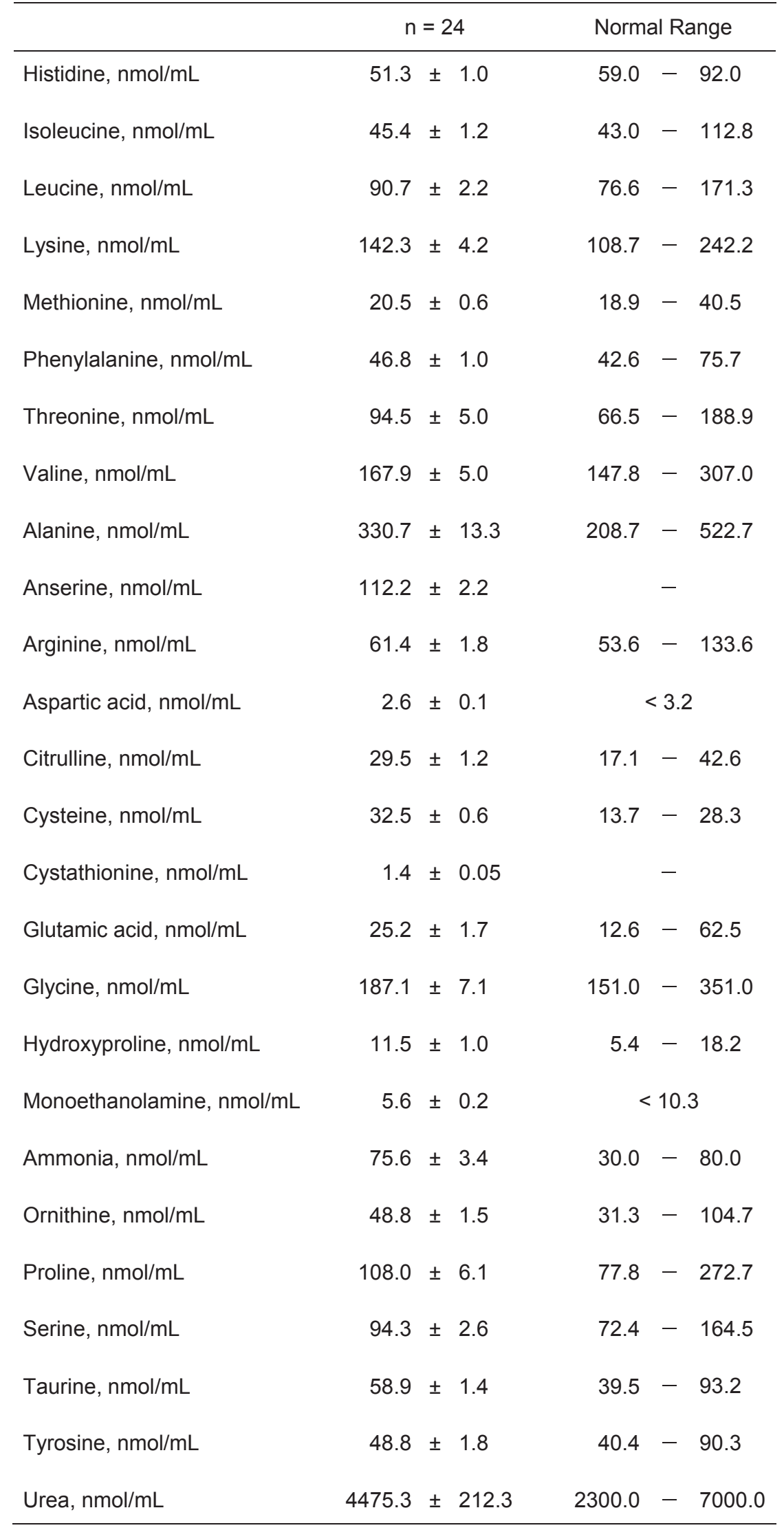

Data are shown as the mean \pm SE. 

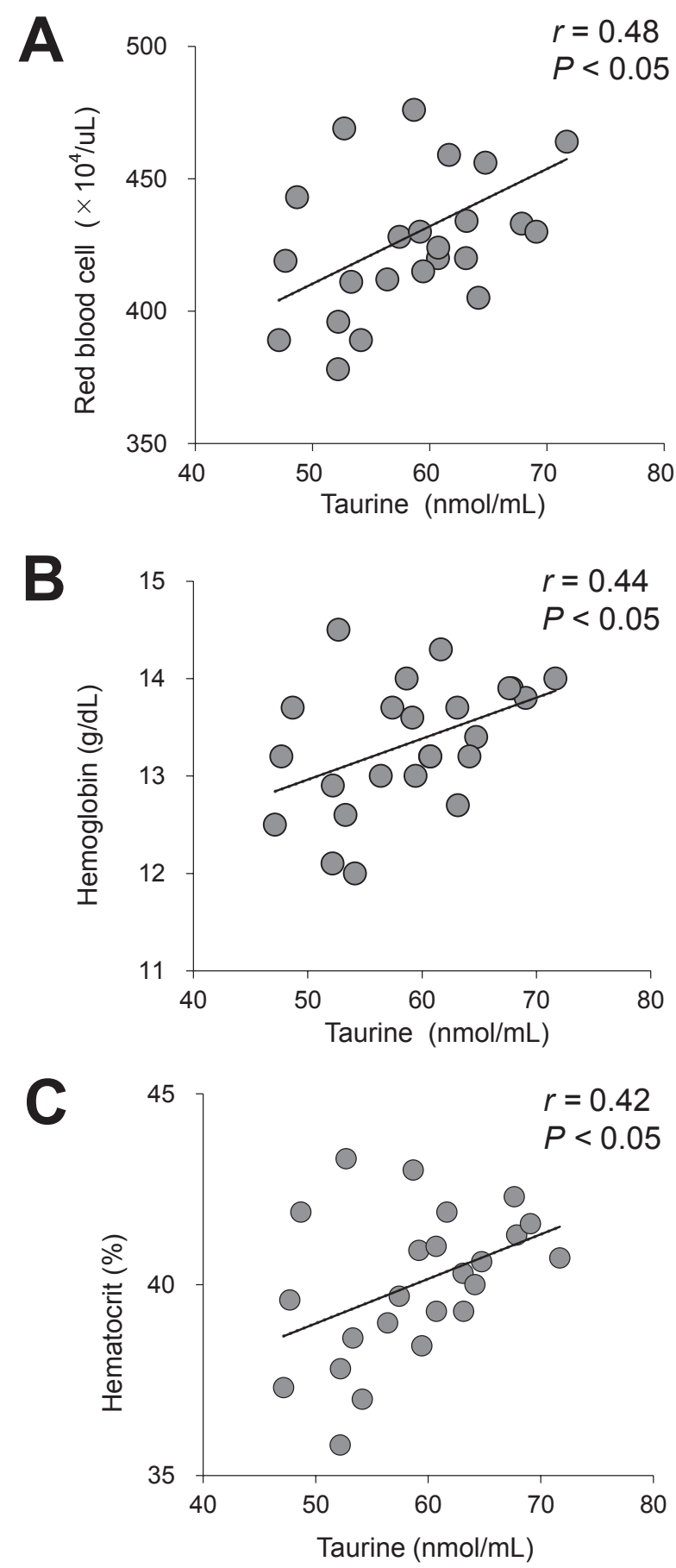

Fig. 1 Relationships between circulating taurine levels and red blood cell (A), hemoglobin levels (B) and hematocrit levels (C) in female endurance athletes.

ヘムとグロビンというタンパク質から構成されるへモグ ロビンが存在しており，このへモグロビンが主に酸素を 取り达む役割を担っている。本研究で着目したアミノ酸 は，生体におけるタンパク質の主要な成分であることか ら，へモグロビンや赤血球などと関連する可能性がある. 実際に，若年女性を対象とした先行研究において，アミ ノ酸の一種であるタウリンの摂取が貧血状態の改善に関 与する可能性が報告されている. Sirdah ら ${ }^{6)}$ は, 若年女
性における20週間の鉄剤およびタウリンの摂取が貧血状 態に及ぼす影響について検討し，鉄剤のみの摂取と比較 して，鉄剤とタウリンの併用摂取により貧血状態を反映 する指標である血中の赤血球数および血中へモグロビン 濃度が大きく改善することを報告している。このことか ら，タウリンの摂取が貧血状態の改善に寄与することが 示唆されている。本研究では女性アスリートの中でも貧 血のリスクが高い陸上競技長距離選手において, 血中夕 ウリン濃度と血中の赤血球数, ヘモグロビン濃度および ヘマトクリット值の間に有意な正の相関関係が認められ た.さらに, 鉄剤やアミノ酸のサプリメント捸取の有無 で補正後も, 血中タウリン濃度と赤血球数には有意な相 関関係が認められ，血中タウリン濃度とへモグロビンお よびへマトクリット值には有意傾向が認められた。これ らのことから, 血中タウリン濃度と貧血マーカーは関連 する可能性が示された，本研究では，貧血のリスクが高 い陸上競技女子長距離選手を対象としていることから， 本研究で得られた結果はスポーツ現場における貧血予防 法の確立に寄与する可能性を有しており，臨床的意義が 大きいと考えられる。しかし，今回の対象者は血中の赤 血球数, ヘモグロビン濃度およびへマトクリット值が正 常範囲内であったことから, 今後は正常範囲よりも低い 対象者を含めた検討を実施する必要がある。

アスリートにおいて，アンモニアは中枢性および末梢 性の疲労を反映する疲労物質であることが明らかにされ ている ${ }^{7-9)}$ 。実際に, 長時間運動や高強度運動により血 中アンモニア濃度が上昇することが報告されている ${ }^{8,9)}$. 本研究では, アンモニアの代謝産物である血中尿素濃度 と 1 週間あたりの練習頻度に有意な正の相関関係が認め られた。本研究の被験者は現役の陸上競技長距離選手で あり，日常的な練習による疲労状態にあると推察される。 このことから，アンモニアの代謝産物である血中尿素濃 度と練習頻度が関連した可能性が考えられる。一方, 本 研究において, アミノ酸の一種である血中リジン濃度と 一週間あたりの練習頻度に有意な負の相関関係が認めら れた。リジンは，エネルギー供給に関連するクエン酸回 路に取り込まれて代謝されるアミノ酸である。このこと から，日常的な練習で多くのエネルギーを必要とする陸 上競技長距離選手において，エネルギー供給に関連する リジンの血中濃度と練習頻度に有意な関連が認められた と考えられる。

本研究において, 陸上競技女子長距離選手の血中夕ウ リン濃度と貧血状態との関連が明らかになったが, アミ ノ酸は運動パフォーマンスとも関連する可能性が報告さ れている。松井ら ${ }^{10)}$ およびRaら ${ }^{11)}$ は, タウリン摂取が 運動後の筋疲労や筋損傷を抑制することを明らかにして いる。また，石倉ら ${ }^{12)}$ は運動中の夕ウリン摂取が心拍数 の上昇を抑制することを報告している，同様に，分岐鎖 
アミノ酸であるBCAAを運動前や運動中に摂取すること で，運動継続時間を延長させることや血中乳酸濃度の上 昇を抑制すること ${ }^{13)}$, 漸増負荷運動時の最大酸素摂取量 が増加すること ${ }^{14)}$, さらに長距離走時の筋損傷を軽減さ せることが報告されている15)。これらの報告から, アミ ノ酸は貧血状態だけでなく運動パフォーマンスとも関連 し，アスリートにおいて非常に重要な役割を果たしてい ると考えられる。

本研究にはいくつかの限界点がある。まず 1 点目とし て, 本研究では血清鉄やフェリチンの測定を行なってお らず，鉄欠乏性貧血について考慮できていない点であ る。女性は月経に伴う出血により貧血になりやすいこと が報告されている16)。さらに，アスリートにおいては運 動に伴う発汗などにより鉄の奕失量が増加することも明 らかになっている ${ }^{17)}$ 。このことから，今後は鉄欠乏性貧 血も考慮した検討が必要である。2 点目として, 対象者 の月経周期を考慮できていない点が挙げられる，本研究 において，続発性無月経を有する者とそうでない者の間 に, 血中の赤血球数, ヘモグロビン濃度, およびへマトク リット值は有意差が認められなかったが, 上述したよう に，月経に伴う出血は鉄欠乏性貧血に関連することが明 らかにされている。このことから, 月経周期や月経状態 は貧血状態に影響する可能性が大きいと考えられる，今 後は月経周期や月経に関する詳細な情報を考慮した検討 が必要である。3 点目として, 対象者の日常的な生活習 慣を調査できていない点である. 貧血の予防や改善には,

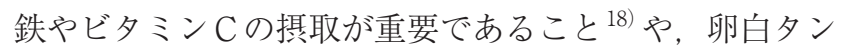
パクは鉄の吸収促進作用を有すること ${ }^{19)}$ が報告されてい る。また，タウリンなどのアミノ酸はイカやタコといっ た魚介類に多く含まれていることや ${ }^{20)}$ 。一過性の運動に より血中濃度が変動することが明らかにされている ${ }^{21)}$. このことから, 日常的な生活習慣が貧血状態や血中アミ ノ酸濃度に影響を及ぼす可能性が考えられる。したがっ て, 今後は生活習慣の調査を含めた検討を行う必要があ る. 最後に, 本研究の対象者はアスリートという特殊な 集団であるが, 対象者数が非常に少ない. 将来的に, 本研 究成果を臨床現場に応用していくためにも, 対象者数を 増やした大規模かつ長期的な検討を実施する必要がある.

本研究では，陸上競技女子長距離選手における血中の 赤血球数, ヘモグロビン濃度およびへマトクリット值と 血中アミノ酸濃度の関連を横断的に検討した。本研究に おいて，アミノ酸の一種である血中夕ウリン濃度が貧血 状態を反映する指標である血中の赤血球数, へモグロビ ン濃度およびへマトクリット值と有意な正の相関関係を 示すことが明らかになった。さらに, 偏相関分析の結果, 鉄剂やアミノ酸のサプリメント摂取の有無で補正後も, 血中タウリン濃度と赤血球数には有意な相関関係が認め られ，血中夕ウリン濃度とへモグロビンおよびへマトク
リット值には有意傾向が認められた。これらの結果から, 陸上競技女子長距離選手において，血中夕ウリン濃度は 血中の赤血球数, ヘモグロビン濃度およびへマトクリッ 卜值と関連し，貧血状態を反映する可能性が示された。

利益相反自己申告：申告すべきものはなし

\section{引用文献}

1）財団法人日本体育協会. Aアスリートにみられる内臓 器官などの疾患 4 血液疾患, 健康管理とスポーツ医 学, (4), 今川重彦, 財団法人日本体育協会, 東京, 17-20, 2009.

2）下村良治, 北浦靖之：スポーツ医学観点からのアミノ酸 機能 分岐鎖アミノ酸 (BCAA) を中心として, 化学と生 物, 52: 143-144, 2014.

3）森本英樹：へモグロビン,生物物理, 21: 1-12, 1981.

4）株式会社 SRL. アミノ酸分析基準值一覧, 株式会社 SRL, 東京, http://test-guide.srl.info/hachioji/test/ detail/00080A40H.

5）三國雅人, 藤本征一郎：研修医のための必修知識 D. 婦 人科疾患の診断 ·治療 - 管理 1 . 内分泌疾患 (1) 月経 異常, 日産婦誌, 54: N552-N560, 2002.

6) Sirdah MM, El-Agouza IM, Abu Shahla AN. Possible ameliorative effect of taurine in the treatment of irondeficiency anaemia in female university students of Gaza, Palestine. Eur J Haematol 69: 236-242, 2002.

7) Mutch BJ, Banister EW. Ammonia metabolism in exercise and fatigue: a review. Med Sci Sports Exers 15: 41-50, 1983.

8) Eriksson LS, Broberg S, Bjorkman O, Wahren J. Ammonia metabolism during exercise in man. Clin Physiol 5: 325-336, 1985.

9) Gorostiaga EM, Navarro-Amézqueta I, Calbet JA, Sánchez-Medina L, Cusso R, Guerrero M, Granados C, González-Izal M, Ibáñez J, Izquierdo M. Blood ammonia and lactate as markers of muscle metabolism during leg press exercise. J Strength Cond Res 28: 27752785, 2014.

10）松井 康, 今井智子, 永井 智, 小林直行, 渡邊昌宏, 近藤 宏, 宮川俊平 : 運動前のタウリン摂取が筋疲労に及ぼす 影響, 理学療法科学, 31: 389-393, 2016.

11) Ra SG, Choi Y, Akazawa N, Ohmori H, Maeda S. Taurine supplementation attenuates delayed increase in exercise-induced arterial stiffness. Appl Physiol Nutr Metab 41: 618-623, 2016.

12）石倉恵介, 宮川俊平, 矢田部佳久, 竹越一博, 大森 肇 : 長 時間運動時の血中グルコース濃度に及ぼすタウリン投 与の影響, 体力科學, 57: 475-483, 2008.

13）足立哲司, 足立博子, 中井 聖, 豊岡示朗, 増原光彦：分岐 鎖アミノ酸 (BCAA) 含有飲料摂取が漸増運動負荷中 の生体に及ぼす影響について, 日本生理人類学会誌, 16 : 165-170, 2011.

14) Matsumoto K, Koba T, Hamada K, Tsujimoto H, Mitsuzono R. Branched-Chain Amino Acid Supplementation Increases the Lactate Threshold during an Incre- 
mental Exercise Test in Trained individuals. $J$ Nutr Sci Vitaminol 55: 52-58, 2009.

15）木場孝繁, 濱田広一郎, 桜井政夫, 松元圭太郎, 早瀬秀樹, 右田孝志, 辻本尚弥, 満園良一：長距離走時の筋損傷に 及ぼす分岐鎖アミノ酸含有飲料摂取の効果, 体力科學, 53: 747, 2004.

16）松田貴雄 : 女性アスリートの諸問題の克服, 臨床スポー ツ医学, 32: 208-212, 2015.

17) Paulev PE, Jordal R, Pedersen NS. Dermal excretion of iron in intensely training athletes. Clin Chim Acta 127: 19-27, 1983.

18）小島菜実絵, 水野秀一, 宮原恵子, 小田和人, 松尾嘉代子, 飯出一秀, 吉村良孝, 田井健太郎, 今村裕行：食事バラン
スと血中貧血検査項目との関係, 総合健診, 41: 274-282, 2014.

19）小林ゆき子, 木戸康博, 中坊幸弘：鉄欠乏性貧血ラット の回復期における食事たんぱく質およびペプチドの影 響, 栄養学雑誌, 65: 165-171, 2007.

20）木林悦子, 鏡森定信：20歳女子の魚介類及びレバー摂取 量による食事中タウリン摂取量の検討, 栄養学雑誌, 60 : 145-153, 2002.

21) Cuisinier C, Michottte De Welle J, Verbeeck RK, Poortmans JR, Ward R, Sturbois X, Francaux M. Role of taurine in osmoregulation during endurance exercise. Eur J Appl Physiol 87: 489-495, 2002. 